\title{
Mutatis Mutandis: The Same Call for Peace, but Differently Framed Each Time
}

An exploration of the significance of the insights generated by New

Philology for the printing and reception history of Georgius Cassander's irenical tract De officio pii viri (1561)

"quia hodie eadem fere semper Scena, saltem mutatis personis ubique locorum agitur"1

\author{
Rob van de Schoor \\ (Translation: Paul Gretton)
}

\section{The Reception of De officio pii viri at the Colloquy at Poissy}

Research into the history of irenicism during the French wars of religion - in particular study of the significance of the Colloquy at Poissy (1561, one of many religious congresses to take place between the Protestants and Roman Catholics during this period) - was given a powerful boost when scholars of ecclesiastical history and the history of dogma began taking account of their own position when interpreting the texts and personalities of the time. Mario Turchetti spoke of the natural sympathy that researchers had for the oppressed French Protestants as a problem for historiography, one that he attempted to solve by examining the changes in meaning and significance that the term "Politiques" had undergone in the course of time as the designation for the irenical party that strove for rapprochement between the denominations. ${ }^{2} \mathrm{His}$ study, together with his monumental survey Concordia o tolleranza? François

1 "because nowadays almost the same performance is put on in every single place, only with different characters": from the title of the second edition of De corruptis moribus (Cracow, 1615), to which the text of De officio pii viri was added.

2 Mario Turchetti, "Une question mal posée : l'origine et l'identité des Politiques au temps des guerres de Religion," in De Michel de L'Hospital à l'Édit de Nantes. Politiques et religion face aux Églises, ed. Thierry Wanegffelen (Collection "Histoires croisées") [n.p.] (2002), pp. 357-90. As far back as 1970, Alain Dufour castigated historians who, "trop prompts à tout expliquer grâce à leur sens psychologique", ascribed the shift in attitude of the King of Navarre, Antoine de Bourbon, to the orthodox Calvinists as being due to weakness of character: Alain Dufour, "Le Colloque de Poissy," in Mélanges d'histoire du XVIe siècle offerts à Henri Meylan (Geneva, 1970), pp. 127-37; pp. 131. 
Bauduin (1520-1573) e $i$ « Moyenneurs » (Milan, 1984), ${ }^{3}$ has made our understanding of the religious wars of the sixteenth century and the underlying theological dispute more fluid, as it were, and ensured that there is scope for discursive study of theological tracts. This innovation in methodology is in line with some of the insights of "New Historicism" and opens up the possibility of investigating whether the principal irenical text of the period, Georgius Cassander's De officio pii viri - and in particular the various reprints of that tract - can be interpreted according to the principles of New Philology. Needless to say, a study of this kind also provides an opportunity to test the validity of these theories.

One of Turchetti's most important achievements, also referred to by Thierry Wanegffelen in his study Ni Rome ni Genève. Des fidèles entre deux chaires en France au XVIe siècle (Paris, 1997), is to have given us a better understanding of Cassander's vision for the "Catholic church" and a future, reunited, Christendom. ${ }^{4}$ By this, Cassander understood not the Roman-Catholic church of the time but the church that was constantly aware of its task and principles, and which was therefore required to constantly reform itself by striving for purity and driving out abuses. Cassander's third way, offered as an alternative to the staunch positions of the Protestants and the Roman Catholics, was the via regia, the "majestic highway" to peace, to which he directed the faithful and which was intended to bring the Catholic church beyond the misleading sideroads of the Reformation and the existing Roman-Catholic church. Turchetti's interpretation of Cassander's concept of the Church makes clear why De officio pii viri had an entirely different impact on the Colloquy at Poissy than Petrus Canisius' contribution had on the Colloquy of Worms in 1557. Canisius appears, at first sight, to deal with the same topics as Cassander, but in fact the Jesuit argues that a church that can be a home for all denominations already existed and it is to the Protestants undoing that they choose to scorn it. Cassander's tract was therefore fiercely denounced not only by Calvin but also criticised on the Catholic side by the Leuven professors Johannes Hessels and Josse de Ravesteyn (Tiletanus).

The actual history of the first edition of De officio and its impact is just as short and painful as that of the Colloquy at Poissy. Because his weak state of health prevented him from accepting Antoine de Bourbon's invitation to

3 The key points of this study are summarised in: Mario Turchetti, "Concorde ou tolérance? Les Moyenneurs à la veille des guerres de religion en France," in Revue de Théologie et de Philosophie 118 (1986), pp. 255-67.

4 Thierry Wanegffelen, Ni Rome ni Genève. Des fidèles entre deux chaires en France au XVIe siècle (Paris, 1997), pp. 115-16; Mario Turchetti, Concordia o tolleranza?, pp. 276-93. 
participate in the Colloquy, Cassander wrote his tract and had it published in Basel, probably by Johannes Oporinus. Whether his friend and supporter François Bauduin undertook to distribute it, or initially attempted to represent himself as its author, cannot be determined. ${ }^{5}$ Bauduin himself later tried to disassociate himself from its authorship, writing that the text was already circulating in France before he was even aware of its existence. ${ }^{6}$ It is clear, however, that Calvin immediately suspected him of being the author and directed an unusually fierce polemic against him. Bauduin defended himself against this attack, and Cassander, still under a pseudonym, published a defence of his innocent little work that had caused so much damage.

The likelihood of the Colloquy at Poissy bringing about a favourable turn of events in the religious wars was not very great from the start, although Cassander had believed that a middle-of-the-road irenicist party had formed itself in France, consisting of Chancellor Michel de L'Hospital, Paul de Foix, Claude d'Espence, and others. The delegates did not trust one another in the slightest: a Protestant participant even wrote home that he was afraid of being poisoned and was more concerned about the soup than about the arguments of the opposing party. ${ }^{7}$ The assertion by Theodore de Bèze, the leader of the Calvinist delegation, that the Body of Christ was as far away from the bread of the Eucharist as heaven was from earth ${ }^{8}$ brought about the rapid disintegration of the Colloquy.

\section{The Contents of De officio pii viri}

The most important message of De officio is the assertion that whoever subscribed to Christian doctrine, recognised Scripture as the basis for the Christian faith, and accepted Christ as his Redeemer was considered to have remained true to the head of the Church. Someone who found himself in another part of the body of the Church than the Roman-Catholic part was

5 See Michael Erbe, François Bauduin (1520-1573). Biographie eines Humanisten (Gütersloh, 1978), pp. 134-35; Michael Erbe, "François Bauduin und Georg Cassander: Dokumente einer Humanistenfreundschaft," in Bibliothèque de l'École des Chartes 3 (1978), pp. 537 sqq.

6 Bauduin, Responsio altera ad Joan. Calvinum (1562), pp. 38, cited by Turchetti, Concordia o toleranza?, pp. 276 .

7 An entertaining account of the Colloquy can be found in Donald Nugent, Ecumenism in the Age of the Reformation: The Colloquy of Poissy (Cambridge, Mass., 1974) (the soup quotation can be found on p. 92).

8 Histoire ecclésiastique des églises réformées au Royaume de France. Édition nouvelle [...] par feu G. Baum et par Ed. Cunitz. Tome premier (Paris, 1883), pp. 574. 
therefore not a heretic; only someone who damned the body of the Church by calling it the home of the Antichrist had unavoidably to be branded a heretic.

The following topics of discussion can be found in the text, explained below with a brief summary of the content:

1. An autobiographical account of the author (1-13), giving his reasons for publishing the work. The experience and insights gained are offered for the consideration of those who have fallen prey to the same kind of religious confusion as the author himself confesses to have suffered from in the past.

2. Scripture and tradition are both indispensable to the Christian faith (1328). Scripture is the sealed tradition, while tradition is the revealed Scripture. Canon doctrinal authority and Catholic tradition are therefore necessary in order to remove the main points of dispute between the denominations, specifically concerning dogmatics and ecclesiastical ceremonies.

3. Dogmatics and rituals/ceremonies (29-69). Dogma's that are true and Catholic are:(1) the doctrine laid down in Scripture; (2) the doctrine brought down to us since the time of the Apostles in accordance with the spirit and meaning of Scripture. There are also (3) doctrines accepted by most of the churches and confirmed by arguments taken from Scripture; and (4) doctrines that are not based on evidence in Scripture or on long tradition but that have been accepted later by the (western) Church. If the latter do not manifestly contradict Scripture, they can be tolerated and religious peace must not be disturbed because of them. If they are contestable, however, or have crept into the Church in the form of abuses that result from malice or misunderstanding, then scholars and moderate persons must discuss whether or not (and if so, how) they can be removed without giving offence.

The rituals or ceremonies that are referred to as "sacraments" (1) are sacred and inviolable. In addition, the rituals that serve to administer or practice the sacraments (2) and the ceremonies to guarantee discipline within the Church (3) are apostolic traditions and universal usages, and their justification is perfectly evident. There are also rituals, however, that have fallen out of use (4); if it can be done without giving offence, they can be dispensed with. Rites that have become somewhat degenerate but that have a long tradition (5) must be respected until the competent authority either does away with them or restores them to their former glory. Time-honoured rituals that have an apostolic tradition but that have slowly fallen into disuse (6) should be reintroduced. Local rituals (7), which often have a long tradition, can be tolerated but it is perhaps a better idea to remove them from the Church because they can threaten the universality of that Church and can form an unnecessary burden on the liturgy. 
4. Religious doctrine (70-95). Despite its shortcomings, the current RomanCatholic Church, in its external manifestation as the guardian of the true faith and apostolic tradition, must be considered as a worthy part of the universal catholic Church. It cannot be denied, however, that there are many within the Roman-Catholic Church who have drawn apart from the Church of Christ and are hostile to Him and His teachings. Furthermore this Church should be embraced to the extent that it corresponds to the Church of Christ; what deviates from the latter can be tolerated as long as it does not harm piety. Contagion from what is corrupt must be avoided. Even so, those cannot be condemned who have begun improving that which required improvement and are doing away with what was wrong, at least as long as they preserve peace. They must be considered to be members of the Church of Christ, even if others condemn them as heretics and schismatics. Those who have turned their back on the Roman-Catholic Church deserve censure, however, because rather than demanding that the Church be healed, they demand that it be ruined and destroyed. Just as blameworthy is the attitude of the Church's administrators, who refuse to hear of any disorders in the health of the Church and who banish from its community those who strive for it to be healed. Nevertheless, the unfortunate fact that the Church pursues its reformers must not be seized upon as a way of depriving it of its designation "Catholic." Those who believe that the Church has therefore become the synagogue of the Devil must be made to see that the Church that they condemn is founded in Christ and that the undeniable fact that Christ's followers have built upon that foundation with timber, hay, and straw rather than with gold, silver, and precious stones does not deprive the Church of its right to exist. But someone who is rejected by the Church, in its blindness, as a heretic is entitled to protest against that rejection.

5. Who are heretics? Only those who condemn the body of the Church as the body of the Antichrist are genuine schismatics (96-135). Even Luther and Calvin held off for a long time from such condemnation. Someone who through no fault of his own, as a result of an excess of religious zeal, has taken the wrong turning that those two indicated does not deserve to be condemned as a heretic. Such a person must be willingly received and cared for as an invalid recovering from a lengthy illness. Scoffing at one another as papists and heretics must be abhorred. Setting up a third, neutral party will not help; it is better to bring the two opposing parties closer to one another by loving one's neighbour. Loving one another is the duty of every true believer nowadays, even if one does not agree with one's neighbour in all respects.

6. Third party. Between the irreconcilable parties - the Lutherans and Calvinists on the one side and the papists on the other - there is a third party $\left(135^{-151}\right)$, that of the mediators, who seek brotherly love and harmony. They 
are in the minority and are oppressed, whereas the rich and powerful always belong to the two irreconcilable parties.

7. Exercising piety in times of strife and uncertainty. The prevailing discord does not stand in the way of true piety (151-178). After all, piety consists of carrying out the tasks that God has imposed on man: believing in Christ the Redeemer and loving one's neighbour.

8. The task of church leaders. Those charged with administering the Church (178-end) must free it of abuses and oppression. They must not deform the faith in order to perpetuate and justify abuses within Church and State from which they profit.

\section{Printing History and Translations of De officio pii viri}

An overview of all the variants of De officio can offer some insight into its printing history. Those variants comprise corrections of printing errors (and the introduction of new ones), changes at the level of words and sentences, and additional content.

Conspectus siglorum

A Basel, [1561]

B S.l., 1562

C Paris, $\mathbf{1 5 6 2 .}$

D Cologne, 1562-1564

E Paris, 1564

F Cologne, 1594

G [Paris], 1607

H Lyon, 1612

J Frankfurt, 1614 (in Melchior Goldast, Politica Imperialia)

$\mathrm{K} \quad$ Cracow, 1615 (in De corruptis moribus)

L [Paris], 1616 (in Cassandri Opera Omnia)

M Mainz, 1619 (in M.-A. de Dominis, De republica ecclesiastica, lib. VIII)

N Lyon \& Strasbourg, 1642

O Königsberg, 1650

P Lyon, 1687

The most striking of the additional changes are two long interpolations in $\mathrm{B}, \mathrm{C}$, $\mathrm{D}$, and the later editions $\mathrm{K}$ and $\mathrm{L}$ ( $\mathrm{L}$ is the edition in Cassander's Opera Omnia). It has been established that B, C, and D - as well as the abbreviated edition $\mathrm{E}$ (1564) which derived from the first generation of reprints - were produced by 
François Bauduin. He would therefore also have been responsible, probably in consultation with Cassander, for the addition of the two interpolations. Those two passages had disappeared again by the next generation of De officio reprints: F, G, and H, among which $\mathrm{F}$ (Cologne 1594) occupies a separate position, also because of other variants that can be found in $\mathrm{G}$ and $\mathrm{H}$ but not in F. F was designated "secunda editio" but on their title page $\mathrm{G}$ and $\mathrm{H}$ assert that they follow the first edition ("postrema editio, iuxta priorem"). The addition of Jean Hotman's syllabus of irenical works in $\mathrm{G}$ and $\mathrm{H}$ makes it clear that Hotman saw these editions through the press; later editions that contain the syllabus therefore derive from these editions. The apparatus of variants demonstrates a relationship between $\mathrm{H}, \mathrm{N}$, and $\mathrm{P}: \mathrm{N}$ is a fairly common edition by the heirs of Lazarus Zetzner from Lyons and Strasbourg of 1642; P is likely to be from the same printing establishment (the title page gives only Lyons as the place of publication) but is from 45 years later and is the final print of De officio of which we are aware.

Between these two generations of reprints lie a number of "miscellaneous" editions: J (Frankfurt, 1614), K (Cracow, 1615), L (Paris, 1616), M (Mainz, 1619), and $\mathrm{O}$ (Königsberg, 1650). L is the edition in Cassander's Opera omnia, for which Cordesius (Jean de Cordes) was responsible. For his edition, Cordesius utilised the first edition of 1561 , but as a true humanist he compared the various prints and included the interpolations that are found in B, C, and D as $A d$ denda in libello de officio pii viri, ex editione anni M.D.LXII. There is no doubt that the edition of De officio in the Opera omnia became the standard edition in the decades that followed, and it was the basis for the later editions $\mathrm{M}$ and O. It is striking that the other editions from the period between the Bauduin and Hotman generations of reprints - J, K, M, and $\mathrm{O}$ - are all from Central Europe, namely from Poland and the domains of Germany (to the east of the Lower Rhine).

$\mathrm{K}$ is a separate case because the person who saw it through the press revised it thoroughly, removing every use of the first person singular; other variants show that the editor made use of B (1562).

K (Cracow, 1615; right) compared to A (1561)

Equidem iam inde ab adolescentia constitutionum et caeremoniarum

Ecclesiasticarum observantissimus fui: sic tamen, ut natura, vel divino potius impulsu, omnem superstitionem, quam tum utcunque deprehendere videbar, vehementer detestatus sim.
Equidem iam inde ab adolescentia constitutionum et caeremoniarum

Ecclesiasticarum observantissimus sit: sic tamen, ut natura, vel divino potius impulsu, omnem superstitionem, quam tum utcunque deprehendere videatur, vehementer detestetur. 
Mox itaque cum in lectionem scriptorum huius aetatis, qui reformationem quandam et repurgationem superstitiosorum cultuum et absurdarum opinionum promittebant, inciderem, mire illorum institutum placuit: qui tamen ita superstitiones et abusiones quae nonnullis caeremoniis Ecclesiasticis admixtae erant, exosas haberem, ut ipsam Ecclesiasticam politiam quae his caeremoniis fere constat, non sublatam et eversam, sed repurgatam et emendatam esse vellem.
Mox itaque cum in lectionem scriptorum huius aetatis, qui reformationem quandam et repurgationem superstitiosorum cultuum et absurdarum opinionum promittunt, inciderit, mire illorum institutum placent: qui tamen ita superstitiones et abusiones quae nonnullis caeremoniis Ecclesiasticis admixtae sunt, exosas habeat, ut ipsam Ecclesiasticam politiam quae his caeremoniis fere constat, non sublatam et eversam, sed repurgatam et emendatam esse velit.

This alteration means that the first part of De officio, without its autobiographical element, becomes less persuasive: there is no longer any "I," not even one who hides his name so as not to stand in the way of an unbiased consideration of the course of his personal development (as described in the text) and the argument that he puts forward. The abbreviated Paris edition of 1564 , E, is also without the autobiographical account at the beginning. With $\mathrm{K}$ (Cracow, 1615), $\mathrm{E}$ can be considered as a strong case in favour of the New Philology perspective because both editions demonstrate the variability even of printed texts, with the author and his auctoritas having been cut from the text.

E (Paris 1564): "Because this treatise is truly of great importance and should be read, precisely at present, in France in particular, it seemed to me a good idea to reprint it in the interest of the state and - now leaving out the chapters that relate more to persons - to very simply and reliably set out the main component of the most important issue; as in a report drawn up by each of the two parties and in which only the issue itself and its cause are to be found, only those things are included and brought together about which the judgment can ultimately be left to judicious and sensible readers."

The anonymized edition of De officio in De corruptis moribus (1615) - even the name of the author is absent in the preliminary matter - was added to what was in fact the second edition of a publication that appeared in 1561 entitled $D e$ corruptis moribus utriusque partis, Pontificorum videlicet, \& Evangelicorum: dia- 
logus lectu jucundus et valde utilis. ${ }^{9}$ It contains a polemic dialogue between two characters: Felix, a Roman-Catholic Polish nobleman, and Sylvester, a Lutheran from Brandenburg. The editor was S. Czekanowski, a pseudonym of Friedrich Staphylus (1512-1564), a follower of Melanchthon who had converted to the Roman-Catholic Church and been brought to Ingolstadt as professor of theology by Petrus Canisius. ${ }^{10}$ References are made in the course of the dialogue to current events in the denominationally divided Poland, in particular the actions of Francesco Stancaro. The Roman-Catholic interlocutor is surprised at these explosive conflicts among the Protestants, while the Lutheran Prussian expresses his indignation at abuses within the Roman-Catholic Church, which had - so to speak - invited the Reformation. The conclusion of this "entertaining dialogue" is that there is a need for tolerance and rapprochement, a conclusion that the editor of the second edition (1615) believed he was supporting by publishing $D e$ officio.

In the Paris edition of 1564 (E; this edition contains only sentences 13-69), the much abbreviated text of De officio is crowded by verbose paratexts, the anti-Calvinist content of which greatly influenced the reading of the irenical tract. The edition opens with two long epistolatory replies from Bauduin to Calvin's accusations of 24 October and 1 November ${ }_{1563}$, followed by a long foreword to the reader by Michael Fabricius (probably a pseudonym of Bauduin himself), ${ }^{11}$ which continues the polemic with Beza. The new edition of De officio, from which the autobiographical motivation and the religious doctrine have been cut, and that consequently contains only the discussion of dogmatic and ceremonial disputes, provides the following justification for its publication:

Because this treatise is truly of great importance and should be read, precisely at present, in France in particular, it seemed to me a good idea to reprint it in the interest of the state and - now leaving out the chapters that relate more to persons - to very simply and reliably set out the main component of the most important issue; as in a report drawn up by each of the two parties and in which only the issue itself and its cause are to be

Rob van de Schoor, "Petrus Canisius' reis naar Polen in 1558 en 1559," in Wegen van kerstening in Europa, 1300-1900, eds. Charles Caspers, Frans Korsten en Peter Nissen (Budel 2005), pp. 66-88: p. 77.

Ute Mennecke-Haustein, "Friedrich Staphylus (1512-1564). Von Wittenberg nach Ingolstadt," in Melanchthon in seinen Schülern. (= Wolfenbütteler Forschungen, Band 73.), ed. Heinz Scheible (Wiesbaden, 1997), pp. 405-26.

11 Mario Turchetti, Concordia o tolleranza?, pp. 66, note 24: "allievo, o forse alter ego, di Bauduin." 
found, only those things are included and brought together about which the judgment can ultimately be left to judicious and sensible readers. ${ }^{12}$

It is understandable that Fabricius/Bauduin scraps the autobiographical motivation for Cassander's search for a third way to peace, a via regia, but he obviously also found the discussion of religious doctrine - which does indeed deal with the radicalisation of Luther's views - to be detrimental to an unbiased reading of the tract. According to the editor, only the central portion of De officio - no more than 56 sentences - remained intact after the attacks of Calvin and Beza.

The view of New Philology that all variants are significant - or can be - is confirmed by a study of the variants of De officio. Printing errors that produce an intelligible and grammatically correct alternative sometimes come to lead a stubborn life of their own, enabling the modern scholar to determine which edition was read by whom. One can conclude with a high degree of certainty, for example, that Georg von Cell's German translation of Cassander's tract was based on B, because of an error in a quotation from Martin Luther, which is translated as Wie sich ein yeder Gottsfürchtiger und des gemeinen Friedes Liebhaber [...] halten soll. In the passage "etiamsi in extremis malis essent, accurreres" etc., B, unlike A, has "maris," with the German translation consequently "an dem eusserstem des Meres, soltestu zu ihnen lauffen."13

This discovery will probably be rather disappointing for adherents of New Philology, given that it does not immediately open up the prospect of the desired colourful alternation of user contexts of variants. A careful study according to the principles of traditional philology would also have noted the difference mentioned. Texts surely are as fluid as New Philologists assert, but they tend to solidify at any arbitrary moment in their existence. The situation is different as regards the following example, where a printed variant is related to a passage from a letter by the author of the text.

A noteworthy alteration in the text of De officio that appears from $1607(\mathrm{G})$ onward is the replacement of "two" by "four" in the sentence "Where there are

"Tandem iis, quae ad personas pertinent, relictis, de reipsa cepit agere, ut libelli sui sententiam defenderet, \& importuni castigatoris fumos discuteret. Quia vero haec disputatio de re magna est, \& est hoc tempore imprimis necessaria, \& vero in Gallia desideratur, visum est, Reipublicae interesse, ut ea recuderetur, ac relictis nunc aliis capitibus, quae ad personas magis referuntur, simplicissime \& optima fide exponeretur summum caput principalis quaestionis, \& veluti utriusque partis acta, quae ad rem causamque pertinent, sola recitarentur, atque committerentur: de quibus deinde iudicium sanis cordatisque lectoribus relinqueretur." ence of the two lengthy passages that are included in $\mathrm{B}$ but not in $\mathrm{A}$. 
now two types of issues regarding faith, the first of which concerns doctrine and the other discipline and ceremonies..."

$\mathrm{G}(1607$, above) compared to A (1561)

Cum autem quaestionum religionis duo sint genera, quarum aliae doctrinam, aliae disciplinam et caeremonias spectant

Cum autem quaestionum religionis quatuor sint genera, quarum aliae disciplinam et caeremonias spectant

In this sentence, the original distribution of the disputed points between dogmatics and ecclesiastical rituals is obscured by the continuation of this alteration: "four issues... some of which concern discipline and ceremonies." It is of course possible that Hotman - because it was he who produced the first edition in which this variant occurs - made the change from two to four because it corresponded more logically with Cassander's following subdivision into four types of issues regarding faith (even though the result is that the rest of the argument becomes incomprehensible), but his omitting the designation of one main category of disputed points, concerning dogmatics, would seem to justify a certain suspicion. Maybe Hotman did not want to worry the reader by explicitly pointing out that the differences between the denominations were also of a dogmatic nature and therefore he preferred to omit the heading under which Cassander had presented his fourfold division of dogma's. If that is in fact the case, then Hotman was applying the same rhetorical trick that Cassander himself had used in his draft of De officio pii viri, as described in the letter that he wrote to Johannes Molinaeus on 23 November 1559. In that letter, he said that he was pondering a reconciliation proposal for Protestants and Roman-Catholics that would consist not of five points, as he had previously announced in print, but of two. The first point, which would be made up of three components, would bring about improvements in the public domain and the second in the private lives of believers. The presentation of the disputed points in De officio in fact turned out differently: a dichotomy between dogmatic and ceremonial issues, subdivided into four and seven sub-categories respectively. (The distinction between the duties of an individual believer and those of a church leader would run throughout the tract.) Hotman specifies four disputed points, some of which concern ceremonial disputes and in fact removes the seven types of rite from his list all together. By not specifying one of the main categories - the most perilous! and obscuring the original subdivision, Hotman may have hoped to make Cassander's inventory of disputed points appear less insurmountable. 
This interpretation of the variants in the 1607 edition involves a fundamental problem. Surely letters are permissible as sources for the interpretation of printed texts, but is it permissible, from a New Philology point of view, to link the author's explicit intentions as they have come down to us in letters written according to the rules of the humanist letter, i.e. the ars conscribendis epistolis, to the author's implicit intentions - such as we derive them from printed texts that emphatically comply with other genre conventions? In the letter, we are dealing with the self-fashioning of the irenicist Cassander, ${ }^{14}$ who divulges his peace-plan-in-preparation to a friend; in De officio, an anonymous narrator anticipates the criticism that may be levelled at his overview of disputed points and the associated statements regarding possible agreement from the Protestant or Roman-Catholic side. Cassander's meandering argument - "can be maintained even if... provided that... but even so abolition is perhaps preferable, although it should be considered in that context that..." - exposes the discursive structure of his peace tract: the reader can write his own objections into the text, as it were, and is then offered an immediate reply. The narrative status of the letter differs fundamentally from that of the persuasive tract; statements in letters can therefore only be applied with the greatest caution in the discursive context of a printed tract.

\section{"Mouvance" and "Variance"}

One unmistakable merit of New Philology is that by introducing new concepts such as mouvance and variance it demands - emphatically - that attention be paid to issues that traditional philology might not always have noticed. ${ }^{15} \mathrm{We}$

14 "Self-fashioning" is used here in the sense Stephen Greenblatt assigns to the term: caught between the existing ideology of the Roman-Catholic Church and hostile Protestantism, Cassanders seeks a genuine solution (inspired by Antiquity) of the dispute between the contesting parties by rephrasing current issues in a humanist letter, intended to be read not just by Molinaeus but by all kindred spirits. Humanist letters more often than not were intended to be printed and published.

15 The concept "mouvance" was originally introduced by Paul Zumthor (Essai de poétique médiévale. Paris, 1972); Bernard Cerquiglini (Éloge de la variante. Histoire critique de la philologie. Paris, 1989) elaborated on Zumthor's theories and noticed "une mobilité incessante et joyeuse de l'écriture medieval" (Éloge de la variante, pp. 114), which he described as "variance." Ingrid Bennewitz, "Alte 'neue' Philologie? Zur Tradition eines Diskurses," in Philologie als Textwissenschaft: alte und neue Horizonte 116 (= Zeitschrift für deutsche Philologie), eds. Helmut Tervooren and Horst Wenzel (1997), pp. 46-61, citation on pp. 51; Thomas Cramer, "Mouvance," in ibid., pp. 150-69; Rüdiger Schnell, "Was ist neu an der 
have been focussing so far on the variance of De officio but it is now important to note that a number of examples of mouvance can also be identified in the life of Cassander's tract, when the text was included as part of lengthier dissertations, for example Politica Imperialia, sive discursus politici, acta publica, et tractatus generales (J, Frankfurt, 1614), De corruptis moribus, qui religionis sanctissimum negotium impediunt (K, Cracow, 1615$)$ or when it was provided with an explanation and commentary by the editor, as was the case in the edition by the Königsberg theologian Johannes Latermann (O, Königsberg, 1650). There, the text no longer speaks for itself alone but is placed in a discursive context. Seen in this way, earlier editions of De officio can also be suspected of mouvance: each edition to which is added the defence of De officio (by Cassander or Bauduin) against the attacks on it by Calvin and Beza - or Hotman's Syllabus of irenical works - is evidence of the failure of Cassander's peace initiative due to the opposing voices that can be heard in them or because the tract is declared to be part of an honourable history of failures. In actual fact, one can already speak of a fundamental mouvance after the first edition in 1561: De officio changes from being a persuasive text with a specific objective into an historical document with arguments and insights that are worthy of consideration but were in fact disregarded.

\section{Readers: Commentators and Translators}

One can gain an impression of the diversity of ideas that De officio pii viri aroused among its widely varying readers during its long life by studying what a number of commentators said - and on occasion printed - about it, as well as the two translations that were made. There is a printed German edition of 1562 by Georg von Cell (Wie sich ein yeder Gottsfürchtiger, und des gemeinen Friedes Liebhaber, in ietzigem werentem zweispalt der Religion halten soll) and a French translation by Jean Hotman (Le debvoir de l'homme de bien et désireux du repos public en ce différent de religion), which is preserved in manuscript form. ${ }^{16}$ The edition of De officio that I am preparing will present the two translations side-by-side with the text of the first edition. The commentary by Johannes Latermann, printed in O, is included as notes to the text. The 1593

'New Philology'? Zum Diskussionsstand in der germanistischen Mediävistik," in Alte und neue Philologie, eds. Martin-Dietrich Gleßgen and Franz Lebsanft (Tübingen, 1997), pp. 61-95.

16 Bibliothèque de la Société de l'Histoire du Protestantisme Français, Paris, Hotmanniana I, no. 7 , fol. $4 \mathrm{rr}-5 \mathrm{ov}$. 
memorandum by the Geneva theologian Charles Perrot, previously published by Guillaume Posthumus Meyjes in the Nederlands Archief voor Kerkgeschiedenis, ${ }^{17}$ will be included as an appendix.

In his critical notes, Perrot, whose irenical convictions led to his papers being confiscated immediately after his death by the Geneva syndic Jean Lect, ${ }^{18}$ primarily attacks Cassander's rhetorical distinctions. He disputes, for example, the allocation of separate duties to ordinary believers (the pii viri of the title) and to persons holding public office within the church. Pursuing this line of thinking, he wonders whether as a private individual Cassander would have felt called upon to publish his views on the condition of the church. Perrot is able to endorse neither the clever argument of presenting the relationship between tradition and Scripture as act and potentia ${ }^{19}$ nor Cassander's broad interpretation of tradition, which rather than focusing on details and dealing with the highly contentious issue of transsubstantiation, allowed Cassander to create a taxonomy of traditions that presented his interpretation as being a matter of course. The same rhetorical strategy of creating subdivisions enables him to present virtually the whole practice of Roman-Catholic ceremonies as bearing an apostolic seal of approval. Perrot seems to have taken offence not so much at the meandering argumentation in De officio as at the rhetorical paradigm that Cassander imposed on these very real differences.

Latermann's Breves \& succintae notae ad tractatum Cassandri De officio pii viri unfold, for the Lutheran (Prussian) reader, Cassander's implicit concessions to the Protestants, with reference to recent Lutheran theological writings. Where he allows himself to make critical remarks about Luther, Cassander is reprimanded, but his veiled criticism of the Roman-Catholic church is given lengthy support in the notes.

One question, at first sight of only minor importance, that arises when presenting Latermann's notes in an edition of De officio is where exactly they should be placed. Should they be added in a separate appendix to the edition of the text of the first version of 1561 , so as to emphasize the difference between the original text and later commentary, or should they be added as footnotes to the original text, among Bible citations or references to other explanations of

17 G.H.M. Posthumus Meyjes, "Charles Perrot (1541-1608). Een onbekend advies van zijn hand over een werk van Georgius Cassander met, in appendix, iets over zijn De extremis in ecclesia vitandis," in $N A K G / D R C H$ 72-1 (1992), pp. 72-91. The text concerned is "Advis sur le livre de Cassander intitulé De officio pii ac publicae tranquillitatis vere amnatis viri," BSHPF, Paris, Hotmanniana II, no. 52, fol. 121r-123v.

18 These papers included the manuscript of De extremis in ecclesia vitandis.

19 These terms are used by Posthumus Meyjes in "Charles Perrot (1541-1608). Een onbekend advies van zijn hand," p. 76 . 
Cassander's tract by traditional philologists? From the point of view of New Philology, this question can be seen as a matter of principle, given that New Philology does not recognise any hierarchy in commentaries, whether created by the author or later editors, though it acknowledges their differences. For the sake of clarity, one could decide that Latermann's notes should be included as an appendix, although it would in fact be more true to the principles of New Philology to annotate each statement by Cassander with everything that anyone had to say about it at any point in its history.

The translations of De officio - that into German by Georgius von Celle and that into French by Jean Hotman - can be investigated in a variety of different ways. Besides the way they reinforce or weaken arguments with the antitheses and nuances that they contain, it is above all the use and expansion of imagery that attracts one's attention in Cassander's tract. ${ }^{20}$ Careful analysis of Cassander's use of metaphors in De officio, which can be considered as a "système métaphorique," 21 shows that they are intended to express the necessity of regulating what has grown - the existence of which is consequently the fault of no one. Hotman succeeds in embellishing his translation with metaphors that reflect this: Cassander's surgeon who must cure a disease is assisted by a French gardener who wishes to uproot weeds. Imagery taken from trade, seamanship and travel, restricted as it is to a peculiar time and space, is carefully translated into German by Georgius von Celle, though it is highly unlikely that his German audience understood these metaphors as easily as Cassander's intended readers would have done.

\section{New Philology, Analytical Bibliography, and a Postmodern/ Post-postmodern Approach to Literature}

New Philology is embraced by some scholars for the same reasons as the over5 os buy themselves a mobile phone or an iPod. Their belief that one cannot afford not to connect with modern trends, even though secretly doubting their usefulness, is very similar to Dietmar Rieger's thinking when he wonders

20 I have referred elsewhere to the significance of metaphors in Cassander's letters: Rob van de Schoor, "Georgius Cassander: Searching for Religious Peace in his Correspondence (1557-1565)," in Between Scylla and Charybdis. Learned Letter Writers Navigating the Reefs of Religious and Political Controversy in Early Modern Europe, eds. Jeanine De Landtsheer and Henk Nellen (Leiden-Boston, 2011), pp. 127-47: pp. 145-47.

21 In the sense assigned to that term by Maarten van Buuren in his dissertation "Les RougonMacquart" d'Émile Zola. De la métaphore au mythe. n.p. 1986. 
whether New Philology is "im Grunde nur viel Lärm um nichts" and whether it would not be better to devote himself to the philological "order of the day." His answer comprises a big "yes" and a little "no": significant shifts in paradigm arise from scholarly (i.e. traditional philological) praxis, never from "Selbstinszenierung und -etikettierung als 'neu." However, anyone who shrugs his shoulders and ignores the New Philology, he warns, runs the risk of missing the initial symptoms of what can develop into a post-postmodern approach to literature, from which a lot of good can be expected. ${ }^{22}$ Rieger's warning is a pertinent one: in the literary theory of the printed book, that tendency has already led to the development of a systemic and institutional approach, discourse analysis, and the revival of the author - previously thought to be "dead" in terms of his contribution to the system of values of the text. In New Philology the author's (or editor's) irrelevance is still a crucial dogma, ${ }^{23}$ secured by the impossibility to identify those who brought about the transformations that a tract like De officio has undergone during its printing history. Surely texts transform according to user contexts - but they don't transform by themselves.

One might argue that the New Philology of the printed book overlaps with New Historicism and discourse analysis. It is in any case noteworthy that no extensive study of the New Philology of the printed book has yet been published. The questions that can be derived from New Philology in the context of medieval studies for the study of early books - from the incunabula until the mid-nineteenth century - have long formed part of the research armoury of analytical bibliography, i.e. the study of printed books. The science of editing concerns itself with the problem of the transformation of the manuscript into a printed text. The innovation that New Philology promises in the study of printed books would therefore seem to lie not primarily in a radical revision of research perspectives, but above all in meeting a need for self-justification and paradigmatic changes.

Dietmar Rieger, “'New Philology'? Einige kritische Bemerkungen aus der Sicht eines Literaturwissenschaftlers," in Alte und neue Philologie, eds. Martin-Dietrich Gleßgen and Franz Lebsanft (Tübingen, 1997), pp. 97-109: p. 98.

One could doubt if this slightly provocative statement is really challenged by the ongoing discussions in Germanic philology. Ingold and Wunderlich e.g. would like to define the medieval author as "Vermittler von bereits Gesagtem": Felix Philipp Ingold und Werner Wunderlich, "Nach dem Autor fragen," in: idem, Fragen nach dem Autor. Positionen und Perspektiven (Konstanz, 1992), pp. 9-18. Recent literature on the subject: Thomas Bein, "Zum 'Autor' im mittelalterlichen Literaturbetrieb und im Diskurs der germanistischen Mediävistik," in Rückkehr des Autors. Zur Erneuerung eines umstrittenen Begriffs, eds. Fotis Jannidis, Gerhard Lauer, Matias Martinez and Simone Winko (Tübingen, 1999), pp. 30320; Thomas Bein, Rüdiger Nutt-Kofoth and Bodo Plachta, Autor - Autorisation - Authentizität (Tübingen, 2004). 